\title{
FAKTOR BERBUAHNYA POHON KURMA (Phoenix dactylifera) DI KAMPUS 2 UIN SUNAN GUNUNG DJATI BANDUNG
}

\author{
Lita Puspa Dewi ${ }^{1}$, Iwan Ridwan Yusup ${ }^{2}$, Lulu Desia Mutiani ${ }^{3}$, Muni Siti \\ Muhayah $^{4}$ \\ 1, 2, 3, ${ }^{4}$ Universitas Islam Negeri Sunan Gunung Djati Bandung; Panyileukan \\ Jl.Cimincrang \\ Kec.Gede bage Kota Bandung, (022) 7800525 \\ e-mail: ${ }^{1}$ Litapuspadewi0@gmail.com, ${ }^{2}$ iwanridwanyusup@uinsgd.ac.id \\ ${ }^{3}$ Iuludesiamutiani24@gmail.com, ${ }^{4}$ muni.sitimuhayah @gmail.com ${ }^{4}$
}

\begin{abstract}
ABSTRAK
Pohon kurma (Phoenix dactylifera) merupakan tanaman yang identik ditanam di Timur Tengah. Begitupula di Indonesia yang merupakan wilayah beriklim tropis yang memungkinkan segala jenis tanaman tumbuh. Namun, di kampus 2 UIN Sunan Gunung Djati Bandung yang memiliki ruang terbuka cukup panas menyebabkan pohon kurma selain dapat tumbuh juga dapat berbuah. Tujuan dari penelitian ini adalah untuk menganalisis faktor pertumbuhan dan perkembangan kurma. Metode penelitian yang dilakukan yaitu observasi dan literature review. Hasil dari penelitian ini, faktor yang mempengaruhi berbuahnya pohon kurma adalah Iklim yang panas, suhu yang tinggi, kelembaban udara yang rendah, $\mathrm{pH}$ tanah dalam keadaan asam maupun toleran terhadap basa dan Kelembaban tanah yang rendah dengan keadaan kering kemudian ketersediaan air yang cukup.
\end{abstract}

Kata Kunci : Kelembaban, pH tanah, Phoenix dactylifera, Suhu

\begin{abstract}
Date palm (Phoenix dactylifera) is an identical plant grown in the Middle East. Neither in Indonesia, which is a tropical climate that makes all types of plants can grow in fertile soil. However, on campus 2 UIN Sunan Gunung Djati Bandung which has open space is quite hot causing the date palm trees to grow but also be able to bear fruit. The purpose of this study was to analyze the growth factors of dates on campus 2 of UIN Sunan Gunung Djati Bandung. The research method used is observation and interviews. The results of this study, the factors affecting date palms are hot climate, high temperatures, low humidity, acidic soil $\mathrm{pH}$ and tolerance to bases and low soil moisture with dry water and then enough water appears.
\end{abstract}

Keywords : Humidity, soil $\mathrm{pH}$, Phoenix dactylifera, Temperature 


\section{PENDAHULUAN}

Iklim, curah hujan dan temperatur selalu berfluktuasi di bumi dan berubah-ubah tiap tahunnya. Iklim dan suhu adalah salah satu faktor utama yang mempengaruhi pertumbuhan buah kurma. Di Indonesia sendiri pohon kurma (Phoenix dactylifera) dapat tumbuh, tetapi tidak semua pohon kurma yang tumbuh dapat berbuah.

Menurut Munns dan Lambers, kekeringan dan efeknya pada tanaman adalah masalah yang paling besar di daerah semi-kering. Masalah yang terkait dengan kekeringan diperkirakan meningkat akibat perubahan iklim global dan dampak oleh manusia. Ketersediaan air yang rendah merupakan faktor lingkungan yang serius. Namun, tanaman diketahui menggunakan strategi yang berbeda untuk mengatasi masalah tersebut, dan strategi ini terkait dengan berbagai sifat adaptif. Ciri-ciri ini terdeteksi melalui berbagai jenis respon, seperti meminimalkan kehilangan air dan memaksimalkan penyerapan air atau mempertahankan penyimpanan internal besar air (Elshibli, Elshibli, \& Korpelainen, 2016).

Kota Bandung yang terletak ditengah provinsi jawa barat memiliki titik kordinat $107^{\circ}$ BT dan $6^{\circ} 55^{\prime}$ LS dengan luas 16.767 Ha (Andikasani, Awaluddin, \& Suprayogi, 2014). Ketinggian kota bandung \pm 768 meter diatas permukaan laut dengan daerah selatan lebih rendah dari daerah utara (Bronto \& Hartono, 2006).
Pohon kurma (Phoenix dactylifera L.) merupakan salah satu tanaman tertua dan utama di Asia Barat Daya dan Afrika Utara. Selain itu, kurma dapat tumbuh di Australia, Meksiko, Amerika Selatan, Afrika selatan, dan Amerika Serikat, terutama di California selatan, Arizona, dan Texas. Pohon kurma termasuk ke dalam famili Arecaceae (Angiospermae, monokotil) yang terdiri dari sekitar 200 genus dan lebih dari 2.500 spesies (Al-Alawi, Al-Mashiqri, Al-Nadabi, Al-Shihi, \& Baqi, 2017).

Nama biologi kurma berasal dari buahnya: phoenix (bahasa Yunani) yang artinya buah merah atau ungu dan "dactylifera" yang artinya "seperti jari" karena gerombol buahnya seperti jari manusia. Pohon kurma merupakan tanaman berumah dua sehingga pohon betina terpisah dengan pohon jantan. Secara alami penyerbukan kurma oleh angin tetapi penyerbukan oleh serangga juga dimungkinkan. Sumber serbuk sari (polen) yang berbeda, akan mempengaruhi ukuran, bentuk biji dan jaringan di sisi luar embrio serta endosperm buah (Chao \& Krueger, 2007). Kurma (Phoenix dactylifera) merupakan pohon monokotil dioecious yang bisa tumbuh sampai 5000 tahun. Beberapa varietas kurma bisa toleran terhadap kekeringan (Djibril et al., 2005). 


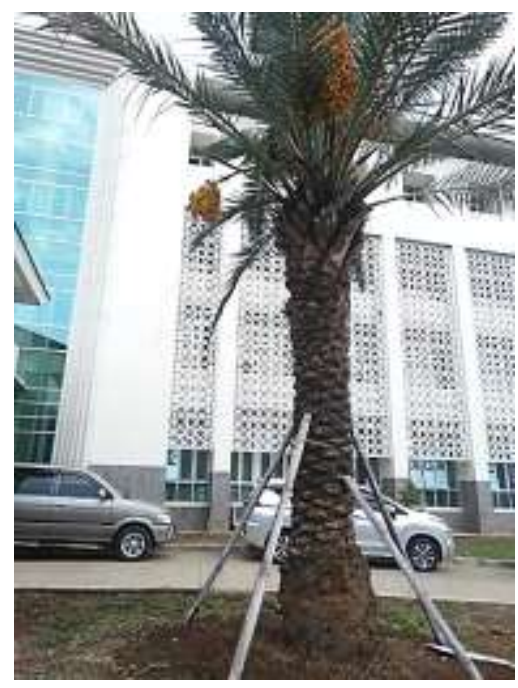

Gambar 1. Pohon Kurma Betina

Menurut Al-Qarawi dan Barghini, buah kurma adalah buah berry yang merupakan buah berbiji tertutup. Buah kurma memiliki tiga bagian yaitu endocarp, mesocarp dan kulit buah (pericarp). Wilayah yang berbeda memberikan perbedaan pada buah kurma dalam bentuk, ukuran, dan berat. Juga dapat bervariasi dalam organoleptik, karakteristik fisik dan kimia (Al-Alawi et al., 2017). Pohon kurma mulai berbuah pada usia ratarata 5 tahun dengan produksi rata-rata 400$600 \mathrm{~kg} /$ pohon / tahun dan terus berproduksi hingga 60 tahun (Al-Alawi et al., 2017).

Bunga pada pohon kurma terletak antara daun yang satu dengan daun yang lain. Berwarna kuning pucat, sepal bersatu, memiliki tiga karpal dan tiga kelopak. Buah dari kurma berbentuk drupes dan berbiji tunggal (Elsafy, Garkava-Gustavsson, \& Mujaju, 2015). Pohon kurma dapat diperbanyak melalui kultur jaringan atau melalui benih (secara vegetatif). Variasi dalam kurma dianggap dihasilkan oleh perbanyakan melalui biji yang menghasilkan genotip (Elsafy et al., 2015).

Langkah yang perlu diperhatikan adalah waktu transisi dari berbunga hingga berbuah karena merupakan awal dari reproduksi seksual (Zhu and Davies, 1993). Suhu yang sesuai untuk pertumbuhan kurma dimulai

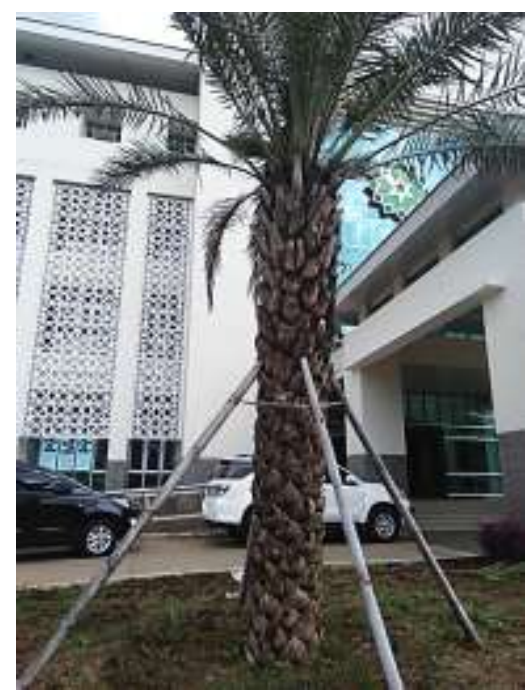

Gambar 2. Pohon Kurma Jantan

saat suhu tinggi atau setelah periode dingin (Zaid and Wet, 2002 dalam(Cheruth, Kurup, \& Subramaniam, 2015). Untuk mengatur pematangan buah kurma adalah suhu yang tinggi. Kurma tumbuh di daerah yang hampir tanpa hujan (EC, CC, \& RU, 2015).

Menurut hasil penelitian (Jassim \& Limoges, 2014), meyebutkan bahwa pertumbuhan kurma tergantung pada iklimnya. Pertumbuhan kurma yang berhasil membutuhkan musim panas yang panjang dengan hari dan malam suhu tinggi, musim dingin yang sejuk tanpa es, tidak adanya hujan selama berbunga dan berbuah, dan kelembaban relatif rendah dengan sinar matahari yang cukup. Sedangkan menurut penelitian (Ningrum \& Narulita, 2018), nilai $\mathrm{pH}$ tanah di Bandung yaitu 6,47 sampai 6,98. Dan menurut (Dianardi, Hadian, Iskandarsyah, \& Muhamadsjah, 2018), Berdasarkan hasil penelitiannya diketahui bahwa telah terjadi pertambahan luasan daerah dengan suhu permukaan di atas $30^{\circ} \mathrm{C}$ di cekungan Bandung pada tahun 20142016.

Hasil penelitian yang didapatkan oleh (Shabani, Kumar, \& Taylor, 2012), bahwa setelah melakukan penelitian menggunakan software CLIMEX, wilayah Afrika Utara yang biasanya cocok untuk pertumbuhan 
pohon kurma ada tahun 2100 nanti menjadi tidak cocok. Sebaliknya, di wilayah Amerika Utara dan Selatan yang biasanya tidak cocok untuk pertumbuhan pohon kurma pada tahun 2100 nanti akan cocok. Menurut (Shabani et al., 2012) untuk mendapatkan buah yang matang ditandai dengan panas yang berkepanjangan, curah hujan rendah, dan tingkat kelembaban yang relatif sangat rendah selama periode pematangan buah. Jika kelembaban tinggi, akan menyebabkan buah pecah dan timbulnya jamur pada tumbuhan kurma. Musim panas yang panjang dengan suhu yang tinggi dan musim dingin yang kering tanpa salju berkepanjangan adalah kondisi iklim yang ideal untuk spesies kurma ini. Suhu optimal untuk pertumbuhan kurma yaitu sekitar $20^{\circ} \mathrm{C}-39^{\circ} \mathrm{C}$

Kesimpulan dari seminar (Rahmadani, Bulkis, \& Budiman, 2017), kurma merupakan salah satu buah yang memiliki

\section{METODE}

Metode penelitian menggunakan teknik observasi ke lapangan dan literature review. Perlakuan yang digunakan terdiri dari faktor suhu, kelembaban udara, Kelembaban tanah dan $\mathrm{pH}$ tanah. Penelitian dilakukan selama 3 hari berturut-turut untuk mendapatkan perbedaan dan rata-rata. Alat yang digunakan untuk penelitian ini adalah thermometer, hygrometer dan soil tester.

\section{HASIL DAN PEMBAHASAN}

Hasil penelitian ini meliputi pengukuran suhu, kelembaban udara, $\mathrm{pH}$ posisi yang sangat istimewa dalam AlQur'an. Al-Qur'an dan al-Hadits secara tersirat menyebutkan bahwa Islam memerintahkan untuk bertanam kurma karena kurma memiliki banyak manfaat dalam kehidupan dan tanaman tersebut pada dasarnya dapat dibudidayakan di berbagai kawasan di muka bumi, termasuk di Indonesia. Secara ekonomis, budidaya kurma mempunyai banyak keunggulan, yaitu dapat memandirikan petani, memiliki tingkat keuntungan yang lebih besar dibanding berkebun sawit, memilik harga pasaran yang tinggi, dan menciptakan industri baru untuk kesejahteraan masyarakat. Sedangkan secara ekologis, budidaya kurma bermanfaat sebagai tanaman tumpangsari, rehabilitasi kawasan daerah operasi minyak dan gas, membuka lahan marginal, dan menyelamatkan dari bencana.

Sedangkan bahan yang digunakan adalah air, tanah dan pohon kurma.

Pohon kurma yang diuji yaitu spesies Phoenix dactylifera. Pohon kurma di tanam dengan cara berdampingan antara jantan dan betina. Buah Kurma berbentuk sedikit ovalsilinder dan berwarna hijau atau kuning jika masih muda dan warna merah pekat kehitam-hitaman jika sudah matang, memiliki kandungan gizi dan nutrisi yang melimpah.

tanah dan kelembaban tanah yang dilakukan selama 3 hari berturut-turut (Tabel 1).

Tabel 1. Hasil Pengukuran Suhu, Kelembaban Udara, pH Tanah dan Kelembaban Tanah

\begin{tabular}{ccccc}
\hline Hari & Suhu & $\begin{array}{c}\text { Kelembaban } \\
\text { Udara }\end{array}$ & $\begin{array}{c}\mathbf{p H} \\
\text { Tanah }\end{array}$ & $\begin{array}{c}\text { Kelembaban } \\
\text { Tanah }\end{array}$ \\
\hline $\mathrm{Ke}-1$ & $30^{\circ} \mathrm{C}$ & $73 \%$ & 6,35 & 2 \\
$\mathrm{Ke}-2$ & $31^{\circ} \mathrm{C}$ & $46 \%$ & 6,1 & 1 \\
\hline
\end{tabular}




$\begin{array}{lllll}\mathrm{Ke}-3 & 30^{\circ} \mathrm{C} & 49 \% & 6,3 & 1\end{array}$

Dalam hasil penelitian selama 3 hari berturut-turut di tempat dan waktu yang sama di dapatkan hasil suhu dengan rata-rata $30^{\circ} \mathrm{C}$ dan kelembaban udara yang berbedabeda. Pada hari pertama kelembaban meningkat $73 \%$ karena cuaca sedang mendung, hari kedua dan ketiga kelembaban diatas $45 \%$ dan dibawah $60 \%$ dalam keadaan normal, $\mathrm{pH}$ tanah dalam keadaan asam, kemudian kelembaban tanah dengan keadaan sangat kering. Pohon kurma membutuhkan iklim yang panas, hujan yang minim, dan akses air yang baik. Kisaran atas toleransi suhu begitu penting untuk pohon kurma. Suhu maksimum yang dapat ditoleransi oleh pohon kurma yaitu sekitar $50^{\circ} \mathrm{C}$ (Barreveld, 1993 dalam (El-Juhany, 2010)).

Menurut penelitian Qureshi dan BarrettLennard, Meskipun kelembaban udara rendah selama air tersedia di bawah tanah pasti akan berbuah (Fatima, Wiehle, Khan, Khan, \& Buerkert, 2016). Kelembaban udara berasal dari samudra yang menguap menjadi uap air. Udara yang lembab disebabkan oleh suhu udara yang tinggi sehingga banyak mengandung uap air karena penguapan lebih besar (Amelia, 2010). Hujan tidak akan turun jika kelembaban $<60 \%$ dan awan akan terbentuk jika kelembaban $>50 \%$. (Dalam (Priyahita, Suguanti, \& Aliah, 2016).

Menurut Chao dan Krueger kurma mampu tumbuh pada iklim yang sangat panas dan kering,dan relative toleran terhadap tanah basa dan bergaram. Kurma memerlukan cuaca musim panas yang panjang dengan sedikit sekali hujan dan

kelembapan yang sangat rendah sejak masa penyerbukan hingga pemanenan, tetapi memiliki air tanah yang cukup. Ada yang menggambarkan kurma sebagai pohon yang kakinya berada dalam air tetapi kepalanya berada dalam kobaran api. Kondisi seperti ditemukan di oase dan wadi di pusat asal kurma di Timur Tengah (Chao \& Krueger, 2007).

Kurma dapat tumbuh pada suhu rata-rata $12.7-27.5^{\circ} \mathrm{C}$, dapat bertahan hingga $50^{\circ} \mathrm{C}$ maupun pada suhu membeku hingga serendah-rendahnya $-5^{\circ} \mathrm{C}$. Suhu ideal untuk pertumbuhan semasa penyerbukan hingga pematangan buah berkisar dari $21-27^{\circ} \mathrm{C}$. Kurma berbunga jika suhu meningkat hingga lebih dari $18^{\circ} \mathrm{C}$ dan membentuk buah jika lebih dari $25^{\circ} \mathrm{C}$ (Chao \& Krueger, 2007).

Kurma dapat memiliki strategi khusus untuk pertukaran gas dan metabolisme fotosintesis. Kurma memiliki lilin kutikula yang tebal pada duri yang merupakan 1/5 1/4 dari daun majemuk (Elshibli et al., 2016). Sehingga dapat meminimalkan kehilangan air dari proses penguapan yang terjadi. Di sisi lain, pohon berhasil dibudidayakan di berbagai jenis tanah dan dapat menyerap air dengan cepat oleh jaringan akar yang mendalam. Ciri-ciri tersebut adalah contoh fitur yang berkontribusi terhadap penurunan penguapan dan penyerapan air dengan maksimal, dan dianggap penting dalam adaptasi kurma di kondisi kekeringan, salinitas dan suhu tinggi (Nixon, 1951; Martin, 1992; Wickens, 1998; Zaid dan de Wet . 2002; Ramoliya dan Pandey, 2003; Djibril et al., 2005 dalam (Elshibli et al., 2016)).

Pemupukan yang efisien tergantung dari pemberian irigasi air yang baik karena nutrisi akan diserap pohon dengan baik jika pemberian air cukup. Saeed et al. (1990), menyatakan bahwa irigasi yang buruk akan mengurangi ukuran, berat dan jumlah buah. Hasil penelitian yang dilakukan oleh Amiri et al. (2007) adalah meningkatnya pertumbuhan pohon kurma juga dipengaruhi 
oleh peningkatan ketersediaan air. Selain itu, system irigasi yang baik juga mempengaruhi jumlah daun, luas daun, kandungan mineral daun dan tinggi pohon. (Dalam (Ibrahim, Saeed, Widaa, \& Elamin, 2012)).

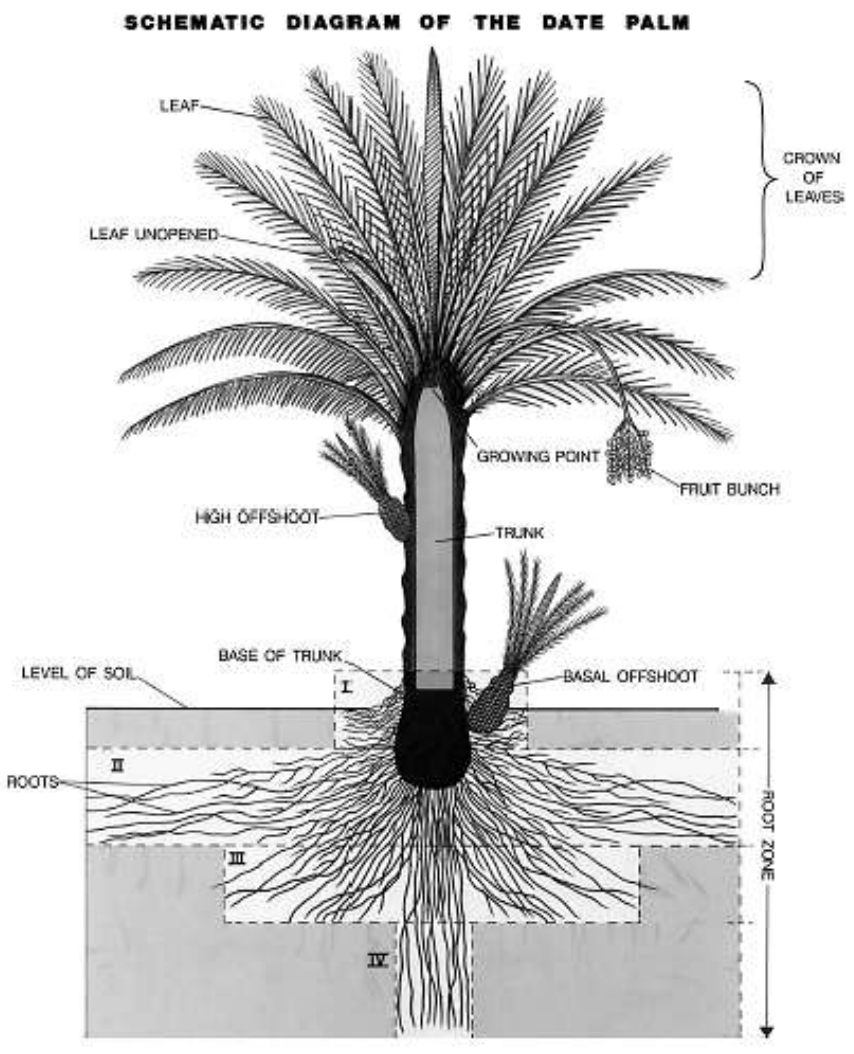

Gambar 3. Morfologi Pohon Kurma

Sumber: (Chao \& Krueger, 2007)

\section{KESIMPULAN}

Hasil penelitian ini meunjukkan bahwa faktor yang mempengaruhi tumbuhnya buah kurma adalah iklim yang panas, suhu yang tinggi, kelembaban udara yang rendah, $\mathrm{pH}$ tanah dalam keadaan asam maupun toleran terhadap basa dan Kelembaban tanah yang rendah dengan keadaan kering kemudian ketersediaan air yang cukup.

\section{DAFTAR PUSTAKA}

Al-Alawi, R., Al-Mashiqri, J. H., Al-Nadabi, J. S. M., Al-Shihi, B. I., \& Baqi, Y. (2017). Date palm tree (Phoenix dactylifera L.): Natural products and therapeutic options. Frontiers in Plant
Science, $\quad 8$ (May), $\quad 1-12$. https://doi.org/10.3389/fpls.2017.0084 5

Andikasani, M. R., Awaluddin, M., \& Suprayogi, A. (2014). Aplikasi Persebaran Objek Wisata Di Kota Semarang Berbasis Mobile Gis Memanfaatkan Smartphone Android. Jurnal Geodesi Undip, 3(2), 28-39.

Bronto, S., \& Hartono, U. (2006). Potensi sumber daya geologi di daerah Cekungan Bandung dan sekitarnya. Indonesian Journal on Geoscience, 1(1), 9-18. https://doi.org/10.17014/ijog.vol1no1. 
$20062 \mathrm{a}$

Chao, C. C. T., \& Krueger, R. R. (2007). The date palm (Phoenix dactylifera L.): Overview of biology, uses, and cultivation. HortScience, 42(5), 10771082.

https://doi.org/10.21273/hortsci.42.5.1 077

Cheruth, A. J., Kurup, S. S., \& Subramaniam, S. (2015). Variations in Hormones and Antioxidant Status in Relation to Flowering in Early, Mid, and Late Varieties of Date Palm (Phoenix dactylifera) of United Arab Emirates. Scientific World Journal, 2015

https://doi.org/10.1155/2015/846104

Dianardi, K., Hadian, S. D., Iskandarsyah, T. Y. W. M., \& Muhamadsjah, F. (2018). Study of Hydrochemistry and Groundwater Characteristics in Cibiru and Cileunyi. Bulletin of Scientific Contribution, 16(2), 71-78.

Djibril, S., Kneyta, M. O., Diouf, D., Diouf, D., Badiane, F. A., Sagna, M., \& Borgel, A. (2005). Growth and development of date palm (Phœnix dactylifera L.) seedlings under drought and salinity stresses. African Journal of Biotechnology, 4(9), 968-972. https://doi.org/10.5897/AJB2005.0003183

EC, N., CC, E., \& RU, A. (2015). Effect of Substitution of Sucrose with Date Palm (Phoenix dactylifera)Fruit on Quality of Bread. Journal of Food Processing \& Technology, 06(09). https://doi.org/10.4172/21577110.1000484

El-Juhany, L. I. (2010). Degradation of date palm trees and date production in Arab countries: Causes and potential rehabilitation. Australian Journal of Basic and Applied Sciences, 4(8), 3998-4010.

https://doi.org/10.1016/j.radphyschem. 2006.10.004

Elsafy, M., Garkava-Gustavsson, L., \& Mujaju, C. (2015). Phenotypic Diversity of Date Palm Cultivars ( Phoenix dactylifera L.) from Sudan Estimated by Vegetative and Fruit Characteristics . International Journal of Biodiversity, 2015, 1-7. https://doi.org/10.1155/2015/610391

Elshibli, S., Elshibli, E. M., \& Korpelainen, H. (2016). Growth and photosynthetic $\mathrm{CO} 2$ responses of date palm plants to water availability. Emirates Journal of Food and Agriculture, 28(1), 58-65. https://doi.org/10.9755/ejfa.2015.05.18 9

Fatima, G., Wiehle, M., Khan, I. A., Khan, A. A., \& Buerkert, A. (2016). EFFECTS of SOIL CHARACTERISTICS and DATE PALM MORPHOLOGICAL DIVERSITY on NUTRITIONAL COMPOSITION of PAKISTANI DATES. Experimental Agriculture, 53(3), 321-338. https://doi.org/10.1017/S00144797160 00399

Ibrahim, Y. M., Saeed, A. B., Widaa, A., \& Elamin, M. (2012). Effect of Irrigation Water Management on Growth of Date Palm offshoots (Phoenix dactylifera) under the River Nile State Conditions. University of Khartoum Journal of Agricultural Sciences, 20(3), 275-285.

Jassim, S. A. A., \& Limoges, R. G. (2014). 
Date Palm Tree's Defense Mechanisms from Viral Infection and Solar Ultraviolet Radiation. Advances in Microbiology, 04(01), 1-5. https://doi.org/10.4236/aim.2014.4100 1

Ningrum, W., \& Narulita, I. (2018). Deteksi

Perubahan Suhu Permukaan

Menggunakan Data Satelit Landsat Multi-Waktu Studi Kasus Cekungan Bandung. Jurnal Teknologi Lingkungan, $\quad 19(2), \quad 145$. https://doi.org/10.29122/jtl.v19i2.2250

Priyahita, F. W., Suguanti, N., \& Aliah, H. (2016). ANALISIS TAMAN ALAT CUACA KOTA BANDUNG DAN SUMEDANG MENGGUNAKAN SATELIT TERRA BERBASIS
PYTHON. ALHAZEN Journal of Physics, 2(2), 28-37. https://doi.org/10.7868/s08695652162 10155

Rahmadani, R. A., Bulkis, S., \& Budiman, M. A. (2017). Potensi Budidaya Kurma di Indonesia Ditinjau dari Perspektif Ekonomis dan Ekologis. Proceedings of National Seminar on ASBIS (Applied Science, Business, and Information System), 427-437.

Shabani, F., Kumar, L., \& Taylor, S. (2012). Climate Change Impacts on the Future Distribution of Date Palms: A Modeling Exercise Using CLIMEX. PLoS ONE, 7(10), 1-12. https://doi.org/10.1371/journal.pone.00 48021 